Tropical Journal of Pharmaceutical Research May 2016; 15 (5): 1099-1108

ISSN: $1596-5996$ (print); 1596-9827 (electronic)

(C) Pharmacotherapy Group, Faculty of Pharmacy, University of Benin, Benin City, 300001 Nigeria.

All rights reserved.

Available online at http://www.tjpr.org

Review Article

http://dx.doi.org/10.4314/tjpr.v15i5.28

\title{
Radioprotective effect and other biological benefits associated with flavonoids
}

\author{
Ya-Na Li ${ }^{1}$, Wen-Bo Zhang ${ }^{2}$, Jin-Hua Zhang ${ }^{1}$, Ping $\mathrm{Xu}^{1 \star}$ and Ming-Hua Hao ${ }^{1}$ \\ ${ }^{1}$ School of Pharmacy, ${ }^{2}$ School of Life Sciences and Technology, Xinxiang Medical University, Xinxiang, 453003, Henan, China
}

${ }^{*}$ For correspondence: Email: 13273730271@163.com; Tel: +86-373-3029879; Fax: +86-373-3029879

Received: 18 March 2015

Revised accepted: 10 February 2016

\begin{abstract}
Ionizing radiation has the potential to cause extensive damage to living organisms. It can directly act on DNA, proteins and lipids, resulting in ionizing excitation and chemical bond cleavage, which can lead to molecular and cellular damage. lonizing radiation can hydrolyze water molecules in the body, resulting in increased numbers of free radicals with strong oxidation ability. This process indirectly leads to tissue degeneration and necrosis, which can possibly result in cancer. In this paper, the intervention mechanism of flavonoids on ionizing radiation was analyzed. It has been revealed that the intervention mechanism associated with flavonoids may offer protective properties for DNA, prevent scavenging free radicals, and protect against auto-immune damage. In addition, this invention mechanism can protect the hematopoietic system and reduce inflammation
\end{abstract}

Keywords: lonizing radiation, Flavonoids, Radioprotective mechanisms, Molecular and cellular damage, DNA, Hematopoietic system, Inflammation

Tropical Journal of Pharmaceutical Research is indexed by Science Citation Index (SciSearch), Scopus, International Pharmaceutical Abstract, Chemical Abstracts, Embase, Index Copernicus, EBSCO, African Index Medicus, JournalSeek, Journal Citation Reports/Science Edition, Directory of Open Access Journals (DOAJ), African Journal Online, Bioline International, Open-J-Gate and Pharmacy Abstracts

\section{INTRODUCTION}

In recent years, with the development of modern science and technology, ionizing radiation technology has been used extensively in several fields including military, medicine, agriculture and industry. As a result, humans are being exposed to greater levels of ionizing radiation than ever before [1,2]. Radiation causes excess production of free radicals in the human body. Free radicals play a significant role in the human body because they can induce damage to cell structure, damage to DNA, protein oxidation, and lipid peroxidation [3-5]. These harmful effects can lead to the dysfunction of hematopoietic and immune systems, accelerate the aging process, and promote degenerative pathological changes $[6,7]$.
Consequently, there is increased importance in the field of radiation protection in the field of radiation therapy. In the early 1920 s, the activity of flavonoids was uncovered. Flavonoids were found to offer several benefits including radiation resistance, reducing inflammation, and slowing the anti-aging process. Currently, studies are focusing on the mechanisms of flavonoids separation and radiation protection. Therefore, it is necessary to analyze the radiation protection mechanism associated with flavonoids.

Flavonoids are polyphenol compounds with 2phenylchromone as the mother nucleus. These compounds most often exist in the free state or in the presence of sugar [8]. Two phenolic hydroxyl benzene rings ( $A$ ring and $B$ ring) are connected into a C6-C3-C6 compound by the central three carbon atoms. The structure is shown in the 
Figure 1. Flavonoids are widely distributed in the plant stems, leaves, and fruits, and generally exist in the plant secondary metabolism.

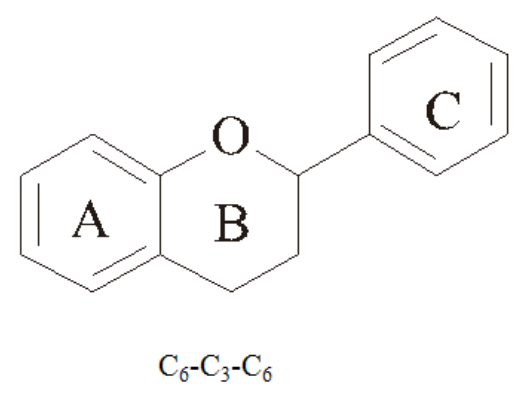

Figure 1: Flavonoid compounds nuclear structure

\section{Classification of flavonoids}

Flavonoids are classified according to the chemical properties of the carbon ring and the number and distribution of phenolic hydroxyl groups. Currently, flavonoids can be classified in over 10 different categories. [9,10].

\section{DAMAGE DUE TO IONIZING RADIATION}

lonizing radiation naturally occurs in several different forms including X-ray, alpha, beta, gamma, and neutrons [11]. The effects of ionizing radiation on the human body may result in a series of complex biochemical changes [12]. Consequently, these changes can lead to several harmful biological effects on the body, resulting in injury or necrosis of the organization [13].

Studies have shown that [14] damage to the human body caused by ionizing radiation can occur through direct and indirect methods (Figure 2). The direct damage of the ionizing radiation occurs when various biological macromolecules in the living organism physically come into contact with ionizing radiation, therefore, directly leading to acute radiation injury. The primary method of indirect radiation damage is caused by free radicals which are derived from water molecules in the irradiated body. Ionizing radiation stimulates the organism to produce strong oxidizing free radicals such as $\cdot \mathrm{OH}, \cdot \mathrm{O}^{2-}$, $\mathrm{H}_{2} \mathrm{O}_{2}$ and NO. These free radicals can interact with the body's biological macromolecules, causing significant changes in the structure and function of the biological macromolecules, resulting in serious radiation damage $[15,16]$.

In general, [17] the main injuries caused by ionizing radiation are DNA damage, immune system damage, and injury of the hematopoietic system. Ionizing radiation can cause DNA damage, resulting in the loss of cell information and degradation of normal cell function which progresses until the cell ultimately dies. Studies have shown that the immune system and hematopoietic system are highly sensitive to radiation. With regards to the immune system, ionizing radiation damage may lead to a reduction in immune cells, decreased immune function, and a reduction in specific and nonspecific immunity within the human body. With regards to the hematopoietic system, in addition to reducing the number of blood cells, ionizing radiation can also lead to suppression of bone marrow microcirculation [18].

\section{RADIOPROTECTIVE MECHANISMS OF FLAVONOIDS}

Natural radioprotection refers to the non-toxic or low-toxic compounds isolated from natural products, which can be used before or after exposure to ionizing radiation to reduce the damage of radiation exposure.

Flavonoids offer several beneficial properties, such as anti-radiation, anti-free radical, antioxidant, antibacterial, antiviral, anticancer, and cancer prevention. In mice, flavonoids have been proven to significantly increase the radiation 30-day survival rate and reduce cell apoptosis and necrosis induced by ionizing radiation [19-21]. The radio-protective mechanisms of flavonoids primarily offer the following benefits: the protection of DNA, antioxidant, immune system protection, hematopoietic system protection, and inflammation reduction.

\section{Reducing DNA damage and genotoxicity}

DNA is the primary target of ionizing radiation damage. DNA damage secondary to exposure to ionizing radiation can result in many harmful effects to the human body. Consequently, reducing the harmful effects of ionizing radiation to DNA is one of the important issues in radioprotective research.

Gandhi [22] used alkaline comet assay technology to investigate the radio-protective effects of bailcalein on DNA damage in irradiated mice. The study found that administration of baicalein, prior to the whole-body exposure to radiation, offered protection against DNA damage. This protection was measured in the blood cells of irradiated mice by alkaline comet assay. The reduced damage in the bone marrow was measured by micronucleus assay. 


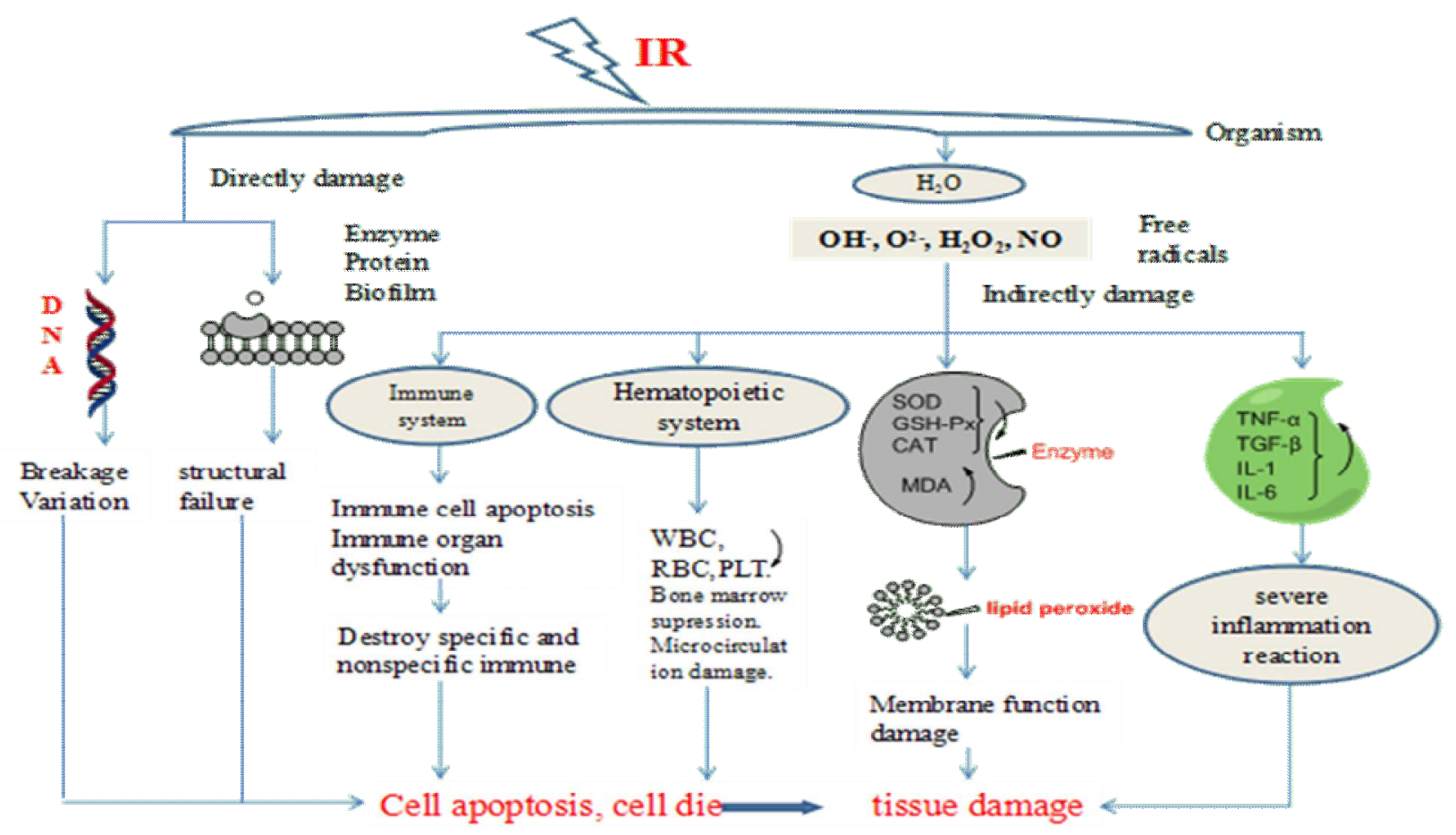

Figure 2: Radiation damage in the body. The mainly direct damage made by the ionizing radiation is directly attack all sorts of biological macromolecules in organisms, such as DNA, protein and phospholipid. Ionizing radiation can cause DNA damage leading to cell information barriers and loss of normal function, until they die. Exposure to ionizing radiation promotes the production of $\cdot \mathrm{OH}, \cdot \mathrm{O}^{2-}, \mathrm{H}_{2} \mathrm{O}_{2}$ and $\mathrm{NO}$ free radiation as a result to water hydrolysis. These free radicals can result in disorders of the immune system and hematopoietic system, membrane function damage, and excessive inflammation leading to tissue damage and cell death

The radiation protection of silibilin was studied in cell and animal experiments. When cells were exposed to 3 Gy radiation, silibinin was proven to reduce the DNA damage and micronuclei formation in lymphocytes. At the same time, oral administration of silibinin to mice prior to wholebody-y-exposure (7.5 Gy) resulted in significant protection for radiation-induced mortality and DNA damage in blood leukocytes. The study indicated that silibinin had a strong potential to prevent radiation-induced DNA damage in vitro and in vivo [23]. Rithidech et al [24] used the cytokinesis-block micronucleus (CBMN) assay to evaluate the radiation protection mechanisms of apigenin. The data showed that apigenin has the radio-protective effect on radiation induced chromosome damage in human lymphocyte cells. Otherwise stated, in a dose dependent manner, apigenin significantly reduces the rate of micronucleus formation.

Xu Ping et al [25] investigated the protective effects of an extract from Guipi Pill against radiation-induced damage. The extract of water extraction-alcohol precipitation (WAP) from Guipi Pill was administered orally to the mice for 6 days prior to whole body radiation ( $8 \mathrm{~Gy}$ ). The experiment found that the pretreatment prior to irradiation with WAP resulted in a significantly higher 30-day survival rate of mice after exposure to a potentially lethal dose of 8-Gy radiation. It has been proven that WAP significantly increases the total white body cell count and DNA content of bone marrow. WAP was also found to be beneficial for increasing the activity of various antioxidant enzymes in liver tissue of mice. In the presence of WAP, malondialdehyde levels and bone marrow micronucleus rate decreased significantly, compared with 6 Gy irradiation group.

In addition, ocimum flavonoids, narigin, procyanidins, hesperidin, propolis flavonoids, and gentianella austriaca flavonoids could also effectively reduce the genetic toxicity which was induced by radiation, and protect DNA from radiation damage [26-31].

\section{Scavenging free radicals and antioxidant effect}

lonizing radiation can stimulate an increase in body moisture to produce a large number of free radicals. Excessive free radicals can decrease SOD, GSH-Px and CAT activities in vivo, resulting in lipid peroxidation, which has the 
potential to cause significant damage to cell membranes of high lipid content. Flavonoids have the ability to effectively remove the oxygen free radicals and eliminate the indirect effects of radiation on the human body, thereby, eliminating the radiation damage in vivo.

Antioxidant capacity of total flavonoids of hops was studied in vitro, which showed that flavonoids from hops had an effective antioxygenation [32]. Flavonoids of hops could enhance the activities of SOD, GSH-Px and $\mathrm{CAT}$, and reduce the content of MDA in irradiated mice. At the same time, it can improve the number of peripheral blood leukocytes, reduce the number of scavenging free radicals in vivo, and offer a protective effect on immune system in irradiated mice. These data indicated that the flavonoids of hops had valuable radioprotective activity in vivo, and the mechanism may be related to the antioxidant activity of flavonoids and modulation of the immune system.

Di [33] investigated the anti-oxidative and protective effect of quercetin, polydatin, and genistein on HaCaT cells injured by UVB radiation. The results showed that each of these compounds had the ability to rid the body of $\mathrm{DPPH}$ and $\mathrm{OH}$ free radicals. The scavenging ability of these compounds was as follow: genistein < polydatin < quercetin. These drugs were applied to act on $\mathrm{HaCaT}$ cells and compared with those treated by UVB irradiation only. The activity of SOD in HaCaT cells was increased $(p<0.05)$ and accompanied by a decrease of TNF- $\alpha$ and MDA level $(p<0.05)$. Those three drugs could inhibit UVB irradiationinduced $\mathrm{HaCaT}$ cell damage. Yu Jin [34] reported that when PC12 cells were incubated with different concentrations of breviscapine for a period of $2 \mathrm{~h}$ prior to being irradiated by $4 \mathrm{~Gy} \mathrm{X}$ rays, a significant decrease could be observed in the level of ROS and MDA. In addition, a significant increase could be observed in function of SOD and T-AOC in PC12 cells, when compared with the irradiation only.

Breviscapine has been proven to effectively remove free radicals induced by radiation, reduce lipid peroxidation, and increase total antioxidant capacity within cells to play the role of radiation protective agent. Ping et al [35] investigated the radio-protective effects of amentoflavone by examining cell viability, apoptosis, relative contents of intracellular ROS, and relative mitochondrial mass by flow cytometry after 60Co irradiation. Pretreatment with amentoflavone for a period of $24 \mathrm{~h}$ prior to 8 Gy $60 \mathrm{Co}$ y-ray irradiation significantly inhibited apoptosis, promoted the G2 phase, and decreased the concentration of ROS and mitochondrial mass. These results collectively indicate that amentoflavone is an effective radioprotective agent.

In addition, hawthorn [36], mimosa, citrus [37] and Chinese wolfberry [38] containing flavonoids also have the ability of removing various free radicals, thus exhibiting significant antioxidant activity.

\section{Immune system protection}

The immune system is an extremely sensitive system in terms of radiation damage. Exposure to ionizing radiation could result in immune function disorders. Exposure to high levels of ionizing radiation can cause failure of the immune system and even death due to decreasing the number of immune cells. lonizing radiation also has the ability to cause a disorder in antibody formation and cytokine network adjustment [39].

Isoflavones are an important class of flavonoids. These flavonoids primarily exist in leguminous plants and offer many benefits such as anticancer, anti-aging, anti-oxidation, regulating cell gene expression, inhibiting apoptosis, and regulating immune function. The immune function of mice treated with 4 Gy radiation, was decreased significantly, especially in thymus and spleen through experimental animal model [40].

The group which added soybean isoflavones showed obvious improvement in the index of the thymus and spleen in mice, reduction of apoptosis of the thymus and spleen cells, reduction in the percentage phase of G0-G1, an increase in the percentage phase of G2-M in irradiated thymus and spleen cells, an increase in the cell proliferation index, and an acceleration of cellular renewal. At the same time, the group that added soybean isoflavones showed a significant increase in macrophage phagocytosis, serum hemolysin level, auricle swelling rate and immune globulin IgA, IgG, IgM levels. These levels were significantly higher than the radiation control group. This indicated that soybean isoflavone had certain protective effect on the immune function of irradiated mice, especially in reducing the radiation injury in the thymus and spleen lymphocytes [41,42]. 
Tong [43] has found that when mice were pretreated with tartary buckwheat flavonoids (TBF) prior to radiation, TBF could increase the spleen index, thymus index, reduce spleen cells apoptosis, alleviate the disorder of spleen $T$ cells and peripheral blood $\mathrm{T}$ cell subsets, and promote peripheral blood WBC recovery in 4.0 Gy $\mathrm{Y}$ - ray irradiated mice. These results indicate that tartary buckwheat flavonoid offer radio-protective mechanisms on the hematopoietic system and immune system.

Studies have shown that flavonoids, such as hesperidin [44-47], apigenin [48,49], quercetin [50-52] and rutin [53-55] could significantly promote lymphocyte proliferation and cytokine secretion, reduce the injury of peripheral blood lymphocytes, and have a significant protective effect on the immune system.

\section{Hematopoietic system protection}

The hematopoietic system is highly sensitive to ionizing radiation. Ionizing radiation targets all types of hematopoietic stem cells and proliferation cells. Therefore, the protection of the hematopoietic system is an important factor to prevent the radiation damage. Experimental research shows that flavonoids can protect hematopoietic organs from radiation damage, and promote the recovery of the hematopoietic system to improve the body's ability to resist radiation damage.

Lin et al [56] treated irradiated mice with the flavonoids of Astragali complanali (FAC). The results of this study found that FAC could increase the number of white blood cells, red blood cells, platelets, and hemoglobin in peripheral blood of irradiated mice. It was also shown that FAC has the ability to improve the 21day survival rate of irradiated mice, and prolong the survival time of mice exposed to ionizing radiation.

Benkovic $[57,58]$ used white blood cell count and comet assay to study the injury of white blood cells in irradiated mice. These studies found that quercetin, water-soluble derivate of propolis (WSDP), and ethanol extract of propolis (EEP), all of which contain a large number of flavonoids, could significantly increase the number of white blood cells in irradiated mice and decrease the damage of leukocyte DNA. Zhou et al [59] found that mice that were pre-treated with genistein before radiation could promote the mice hematopoietic system and increase the survival rate. In addition, genistein also stimulated the recovery of leukocytes, erythrocytes, lymphocytes, and thrombocytes in irradiated mice. At the same time, pre-treatment with genistein could increase the formation of granulocyte colony stimulating factors in irradiated mice and promote the regeneration of the hematopoietic stem cells. In experimental mice, Ping et al [60] found that administration of troxerutin before irradiation provided a higher survival rate, improvement of biochemical parameters, and preserved major histological parameters of the liver. These results collectively indicate that troxerutin is an effective radioprotective agent.

Wenxiu et al [61] used a nanoparticle suspension of genistein, instead of genistein dissolved in water, to evaluate the radio-protective effect on survival and hematopoietic recovery in mice exposed to total-body gamma radiation. Genstein nanosuspension resulted in a 30-day survival rate of $95 \%$ compared to $25 \%$ in vehicle-treated animals, increased mouse bone marrow cellularity from approximately $2.9 \%$ (vehicle treated) to $28.3 \%$ on day 7 of post-irradiation, decreased hematopoietic stem and progenitor cell death from 77 to $43.9 \%$, and attenuated the radiation-induced elevation of pro-inflammatory factors interleukin 1 beta (IL-1 $\beta$ ), IL-6 and cyclooxygenase-2 (COX-2) in mouse bone marrow and spleen, which may assist in the protection of the hematopoietic system and prevent pro-inflammatory factors activation.

\section{Reduction in inflammation}

Exposure to large amounts of ionizing radiation could result in a severe inflammation reaction. Inflammatory cytokines could be applied to tissues and organs of each part of the body, causing damage to tissue cells and causing degeneration and necrosis in tissue cells. This type of damage most commonly occurs in the lungs and kidneys.

In mice, Hillman et al [62] investigated the role of soy isoflavones in the radiation protection of lung tissue. Histological examination of irradiated lungs revealed a chronic inflammatory infiltration involving the alveoli and bronchioles and a progressive increase in fibrosis. These adverse effects of radiation were alleviated by soy isoflavones administered either before or after radiation.

Wang [63] administered flavonoids extracted from Astragalus complanatus to mice after exposure to 10 Gy radiation. The study showed 
that flavonoids could significantly increase the serum level of SOD, decrease the serum level of TGF- $\beta 1$, TNF- $\alpha$ and IL- 6 in irradiated mice, and alleviated the lung injury induced by radiation. Yuan Hu [64] had found that administering green tea polyphenols to mice before radiation could increase the 21-day survival rate and reduce the elevated serum inflammatory cytokines (TNF- $\alpha$, IL-1 and IL-6), which can be developed as radioprotective agents against radiation-induced toxicity.

Lee [65] found that baicalein can suppress radiation-induced inflammatory response by negatively regulating NF-KB and up-regulating FOXOs activation, CAT, and SOD activities. Furthermore, baicalein could inhibit radiationinduced phosphorylation of MAPKs and Akt, which were the upstream kinases of NF-KB and FOXOs. These studies concluded that baicalein had a radio-protective effect against NF-KB mediated inflammatory response through the MAPKs and Akt pathway, which had a significant radio-protective effect in the kidneys of mice.

Additionally, propolis flavonoids [66-68], glabridin [69], austragalus [70,71] and flavonoids of Oxytropis falcate Bunge also inhibited the secretion of inflammatory factors secondary to radiation exposure, and reduced the body's inflammatory response.

\section{Other protective effects}

Flavonoids not only offer a significant radioprotective effect, but also have obvious antitumor, anti-viral, anti-bacterial, and antiinflammatory effects.

The study showed that 5, 7-dihydroxy flavonoids had the ability to weaken the body lipid peroxidation, improve the activity of xanthine oxidase, and decrease P38 activation and the expression of P53 phosphorylation, which could inhibit colon cancer induced by cisplatin [72]. The study examining 13 flavonoids, separated from Humifuse Euphorbia Herb extraction, had been found that the flavonoids had the anti-HBV activity. The antiviral activity of flavonoids, which used apigenin as parent nucleus, was obviously higher than those that used luteolin and quercetin as parent nucleus. The study had also found that the antiviral activity (flavonoid glycoside > yellow ketone glucoside) and toxicity (yellow ketone > flavonoids single nucleotides sugar > luteolin glucoside) could significantly be influenced by the number of glucosides in the compound [73].

In addition, through investigating the antibacterial and antifungal properties of six different kinds of plant flavonoids, these compounds showed significant inhibition effect on Pseudomonas aeruginosa, Acinetobacter baumannii, Staphylococcus, and Candida in range of 32 $128 \mathrm{mg} / \mathrm{mL}$. Meanwhile, rutin, 5,7-dimethoxyflavanone-4'-O- $\beta$-D-glycopyranoside and 5,7,3'trihydroxy-flavanone-4'-O- $\beta$-D-glucopyranoside glucoside could significantly inhibit the HSV-1 herpes simplex virus [74].

\section{MOLECULAR MECHANISMS OF RADIATION PROTECTION}

Numerous studies have indicated that flavonoids offer significant benefits regarding radiation protection. The studies on the molecular mechanism of radiation protection were primarily protein molecules and signaling pathways focused on the induction of apoptosis.

Liu Wei et al [75] used Western and RT-PCR techniques to study the radiation protection effect of blueberry anthocyanins.

Table 1: Flavonoids Radioprotective mechanisms. ( $\uparrow$ denotes induction; $\downarrow$ is inhibition)

\begin{tabular}{ll}
\hline \multirow{2}{*}{ Reduce DNA damage } & Decrease DNA rupture [22] \\
& Reduce micronuclei formation [23] \\
& Reduce chromosome lesion [24] \\
Antioxidant & Scavenging free radicals [33] \\
& Reduced lipid peroxidation [34] \\
Protection of immune & The index of thymus and spleen $\uparrow[41]$ \\
system & Globulin IgA, IgG, IgM level $\uparrow[42]$ \\
& Lymphocyte apoptosis $\downarrow$ [43] \\
Protection of hemopoietic & Recovery of peripheral blood cells $\uparrow[56]$ \\
system & Regeneration of the hematopoietic stem cells $\uparrow[59]$ \\
Reduce inflammation & Protect of bone marrow [61] \\
& TGF- $\beta 1$, TNF- $\alpha$, IL-1 and IL-6 $\downarrow[64]$ \\
& P-MAPKs and p-Akt $\downarrow[65]$ \\
\hline
\end{tabular}


The study showed that blueberry anthocyanins could significantly inhibit cell apoptosis and reduce the radiation injury by decreasing gene and protein expression of p53, phosphor-p53 (Ser15), and p21 in UV-irradiated HepG2 cells. Shin [76] treated a fibroblast cell with epicatechin prior to exposure to radiation to verify the radiation protection function. The study showed that epicatechin could significantly reduce the expression of $\mathrm{p}$-JNK, $\mathrm{p}-38$, cleaved caspase-3 compared with their significant increase after radiation treatment, and inhibited radiationinduced ROS generation, mitochondrial dysfunction, and cell death. At the same time, epicatechin could attenuate the radiation-induced embryotoxicity in a zebrafish model. This represented an effective means of reducing cellular damage and facilitating wound healing after radiation exposure.

Singh [77] treated mice with genistein for a period of 24 hours prior to radiation (7 Gy 60Co), quantified serum cytokine levels by multiplex Luminex, and also investigated numerous cytokines using cytokine assays. Genistein administration stimulated serum granulocyte colony stimulating factor (G-CSF) and interleukin-6 (IL-6) after irradiation. Considering G-CSF and IL-6 are important hematopoietic factors, these results indicated that the radioprotective efficacy of genistein may result in the recovery of hematopoietic cells due to enhancing the production of G-CSF and IL-6.

\section{CONCLUSION}

Flavonoids offer a variety of beneficial properties including protection from ionizing radiation, DNA protection, immune system protection, hemopoietic system protection, scavenging of free radicals, antioxidant properties, antitumor properties, antiviral properties, antibacterial properties, and anti-inflammatory properties. Despite great advances, the specific protective mechanism and the relationship between the protective mechanism is not yet clear and further investigation is required.

\section{ACKNOWLEDGEMENT}

This study was supported by the National Natural Science Foundation of China (project no. U1504824), the Department of Science and Technology Research Project of Henan Province in China (project no. 142102310302) and the Department of Education Science and Technology Research Project of Henan Province in China (project no. 12B310018).

\section{CONFLICT OF INTEREST}

No conflict of interest associated with this work.

\section{CONTRIBUTION OF AUTHORS}

We declare that this work was done by the authors named in this article and all liabilities pertaining to claims relating to the content of this article will be borne by the authors.

\section{REFERENCES}

1. Augustine $A D$, Gondré-Lewis $T$, McBride W, Miller L, Pellmar TC, Rockwell S. Animal models for radiation injury, protection and therapy.Radiat Res 2005; 1: 100109.

2. Citrin D, Cotrim AP, Hyodo F, Baum BJ, Krishna MC, Mitchell JB. Radioprotectors and Mitigators of RadiationInduced Normal Tissue Injury. Oncologist 2010; 15: 360371.

3. Vasilyeval IN, Bespalov VG. Release of Extracellular DNA after Administration of Radioprotective Combination of $\alpha$-Tocopherol and Ascorbic Acid. Radiats Biol Radioecol 2015; 5: 495-500.

4. Turick CE, Ekechukwu AA, Milliken CE, Casadevall A, Dadachova $E$. Gamma radiation interacts with melanin to alter its oxidation-reduction potential and results in electric current production. Bioelectrochemistry 2011; 1 : 69-73.

5. Georgieva S, Popov B, Bonev G. Radioprotective effect of Haberlea rhodopensis (Friv.) leaf extract on gammaradiation-induced DNA damage, lipid peroxidation and antioxidant levels in rabbit blood. Indian J Exp Biol 2013; 1:29-36.

6. Cui YF, Du L. Radiation immune injury and its protection. Radiation Protection Bulletin 2009; 5: 19-24.

7. Li Z, LiU W, Li QT, Shang XM, Qiao JW, Hou DJ. The influence on the healthy condition of professional workers for long-term exposure to low-dose ionizing radiation. Chinese Journal of Radiological Health 2009; 18: 11-12.

8. Pietta PG. Flavonoids as Antioxidants. J Nat Prod 2000; 63: 1035-1042.

9. Catherine RE. Flavonoids and isoflavones: absorption, metabolism, and bioactivity. Free Radic Biol Med 2004; 36: 827-828.

10. Douglas R, Spitz, Edouard IA, Li JJ, Gius D. Metabolic oxidation/reduction reactions and cellular responses to ionizing radiation: $A$ unifying concept in stress response biology. Cancer Metast Rev 2004; 23: 311-322.

11. Crump KS, Duport $P$, Jiang $H$, Shilnikova NS, Krewski $D$, Zielinski JM. A meta-analysis of evidence for hormesis in animal radiation carcinogenesis, including a discussion of potential pitfalls in statistical analyses to detect hormesis. J Toxicol Environ Health $B$ Crit Rev 2012; 3: 210-231. 
12. Friedman DA, Tait L, Vaughan AT. Influence of nuclear structure on the formation of radiation-induced lethal lesions. Int J Radiat Biol 2016; 26: 1-12.

13. Nikjoo $H$, Bolton $C E$, Watanabe $R$, Terrissol M, O'Neill $P$, Goodhead DT. Modelling of DNA damage induced by energetic electrons (100 eV to $100 \mathrm{keV}$ ). Radiat Prot Dosim 2002; 99: 77-80.

14. Widet M, Przybyszewski W, Rzeszowska-Wolny J. [Radiation-induced bystander effect: the important part of ionizing radiation response. Potential clinical implications]. Postepy Hig Med Dosw (Online) 2009; 63:377-88.

15. Azzam El, Jay-Gerin JP, Pain D. lonizing radiationinduced metabolic oxidative stress and prolonged cell injury. Cancer Lett 2012; 327: 48-60.

16. Sankaranarayanan K. Estimation of the genetic risks of exposure to ionizing radiation in humans: current status and emerging perspectives. J Radiat Res 2006; 47: 5766.

17. Srinivasan $M$, Sudheer AR, Pillai KR, Kumar $P R$, Sudhakaran PR, Menon VP. Lycopene as a natural protector against gamma-radiation induced DNA damage, lipid peroxidation and antioxidant status in primary culture of isolated rat hepatocytes in vitro. Biochim Biophys Acta 2007; 4:659-665.

18. Zhang $X D$, Ma $C$, Sun $X$, Zhang $K$. Research progress of natural drug antiradiation effect. Chinese Journal of Radiological Health 2004; 13: 228-230.

19. Xu P, Jia JQ, Jia JF, Jiang EJ. Radioprotective effects of troxerutin against gamma irradiation in V79 Cells and Mice. Asian Pacific J Cancer Prev 2011: 12: 2593-2596.

20. Xu P, Zhang WB, Cai XH, Lu DD, He XY, Qiu PY, Wu J. Flavonoids of rosa roxburghii tratt act as radioprotectors. Asian Pac J Cancer Prev 2014; 15: 8171-8175.

21. Guo XL. Hops flavonoids extraction and study of the radiation. Tianjin: Tianjin University of Science and Technology 2012.

22. Gandhi NM. Baicalein protects mice against radiationinduced DNA damages and genotoxicity. Mol Cell Biochem 2013; 379: 277-281.

23. Tiwari $P$, Kumar A, Ali M, Mishra KP. Radioprotection of plasmid and cellular DNA and Swiss mice by silibinin. Mutat Res-Fund Mol M 2010; 695: 55-60.

24. Rithidech KN, Tungjai $M$, Whorton EB. Protective effect of apigenin on radiation-induced chromosomal damage in human lymphocytes. Mutat Res-Fund Mol M 2005; 585: 96-104.

25. Xu P, Jia JQ, Jiang EJ, Kang LP, Wu KL. Protective effect of an extract of guipi pill against radiation-induced damage in mice. Chin J Integr Med 2012; 18: 490-495.

26. Devi PU, Bisht KS, Vinitha M. A comparative study of radioprotection by ocimum flavonoids and synthetic aminothiol protectors in the mouse. Brit J Radiol 1998; 71: $782-784$.

27. Jagetia GC, Venkatesha VA, Reddy Tk. Naringin, a citrus flavonone, protects against radiation-induced chromosome damage in mouse bone marrow. Mutagenesis 2003; 18: 337-343.
28. Castillo J, Benavente-García O, Lorente J, Alcaraz M, Redondo M, Ortuño A, Del Ron JA. Antioxidant activity and radioprotective effects against chromosomal damage induced in vivo by $X$-rays of flavan-3-ols (procyanidins) from grape seeds (vitis vinifera): comparative study versus other phenolic and organic compounds. J Agric Food Chem 2000; 48: 1738-1745.

29. Hosseinimehr SJ, Mahmoudzadeh A, Ahmadi A, Mohamadifar S, Akhlaghpoor S. Radioprotective effects of hesperidin against genotoxicity induced by gammairradiation in human lymphocytes. Mutagenesis 2009; 24: 233-235.

30. Benkovic V, Knezevic AH, Orsolic N, Basic I, Ramic S, Viculin $T$, Knezevic $F$, Kopjar $N$. Evaluation of radioprotective effects of propolis and its flavonoid constituents: in vitro study on human white blood cells. Phytother Res 2009; 23: 1159-1168.

31. Moon HI, Jeong MH, Jo WS. Protective activity of Cgeranylflavonoid analogs from Paulownia tomentosa against DNA damage in $137 \mathrm{Cs}$ irradiated $\mathrm{AHH}-1$ cells. Nat Prod Commun 2014; 9:1295-8.

32. Ha CT, Li XH, Fu D, Xiao M, Landauer MR. Genistein nanoparticles protect mouse hematopoietic system and prevent proinflammatory factors after gamma irradiation. Radiat Res 2013; 180:316-325.

33. Zhang $D$, Wang JB, Li WF, Xu B. Study on antioxidant activities of quercetin, polydain and genisten and the protection on $\mathrm{HaCaT}$ cells against damage from UVB irradiation. Chin J Clincians 2013; 7: 5387-5391.

34. Yu J. Flavonoids protection against ionizing radiation induced PC12 cell injury and its machine system research. Hubei: Hubei University of Chinese Medicine 2012.

35. Xu P, Jiang EJ, Wen SY, Lu DD. Amentoflavone acts as a radioprotector for irradiated $V 79$ cells by ragulating reactive oxygen species (ROS), cell cycle and mitochondrial mass. Asian Pac J Cancer Prev 2014; 15: 7521-7526.

36. Hosseinimehr SJ, Azadbakht M, Mousavi SM, Mahmoudzadeh A, Akhlaghpoor S. Radioprotective effects of hawthorn fruit extract against gamma irradiation in mouse bone marrow cells. J Radiat Res 2007; 48: 63-68.

37. Pradeep K, Ko KC, Choi MH, Kang JA, Chung YJ, Park $\mathrm{SH}$. Protective effect of hesperidin, a citrus flavanoglycone, against $y$-radiation-induced tissue damage in Sprague-Dawley rats. J Med Food 2012; 15: 419-427.

38. Hsu HY, Yang JJ, Ho YH, Lin CC. Difference in the effects of radioprotection between aerial and root parts of Lycium chinense. J Ethnopharmacol 1999; 64; 101 108

39. He XL, Lu XZ, Chen $M, Y e H$, Zhou ZH, Zhang SY. Research progress of immune organs radiation damage and protect. Progress in Modern Biomedicine 2014; 5: 997-1000.

40. Liu L, Jin H, Wang $X Y, X u Z Q$, Nan WK, Li PB. Effects of soybean isoflavones on the cell cycles, the cell

Trop J Pharm Res, May 2016; 15(5): 1106 
apoptosis and the proliferation of spleen in radiated mice. Chinese Journal of Applied Physiology 2006; 22 : 497-500.

41. Liu L, Jin H, Wang $X Y, X u Z Q$, Nan WK, Li PB. Effects of soybean isoflavones on the cell cycles, the cell apoptosis and the proliferation of thymus in radiated mice. Journal of Nutrition 2006; 28: 311-317.

42. Jia $H Q$, Jin $H$, Li $P B$, Wu JQ, Nan WK, Wang $Y H$, Deng $B N$, Gao $L X$. Effects of soybean isoflavones on immune function in irradiation mice. J Prev Med Chin PLA 2011; 06: $402-404$.

43. Tong HL. Radioprotective effects of tartary buckwheat flavonoids on mice and its mechanism. BeiJing: PLA Academy of Military Medical Education 2011.

44. Katoch O, Kaushik S, Kumar MS, Agrawala PK, Misra K. Radioprotective property of an aqueous extract from valeriana wallichii. J Pharm Bioallied Sci 2012; 4: 327332.

45. Kalpana KB, Devipriya N, Srinivasan $M$, Vishwanathan $P$, Thayalan K, Menon VP. Evaluating the radioprotective effect of hesperidin in the liver of Swiss albino mice. Eur J Pharmacol 2011; 658: 206-212.

46. Kalpana KB, Devipriya $N$, Srinivasan M, Menon VP. Investigation of the radioprotective efficacy of hesperidin against gamma-radiation induced cellular damage in cultured human peripheral blood lymphocytes. Mutat Res 2009; 676: 54-61.

47. Hosseinimehr SJ, Nemati A. Radioprotective effects of hesperidin against gamma irradiation in mouse bone marrow cells. Br J Radiol 2006; 79: 415-418.

48. Hien TV, Huong NB, Hung PM, Duc NB. Radioprotective effects of vitexina for breast cancer patients undergoing radiotherapy with cobalt-60. Integr Cancer Ther 2002; 1 : 38-43.

49. Uma DP, Ganasoundari A, Rao BS, Srinivasan KK. In vivo radioprotection by ocimum flavonoids: survival of mice. Radiat Res 1999; 151: 74-78.

50. Zbikowska HM, Antosik A, Szejk M, Bijak M, Olejnik AK, Saluk J, Nowak $P$. Does quercetin protect human red blood cell membranes against $y$-irradiation? Redox Rep 2014; 19: 65-71.

51. Das DK, Chakraborty A, Sinha M, Manna K, Mukherjee $D$, Chakraborty A, Bhattacharjee S, Dey S. Modulatory role of quercetin against gamma radiation-mediated biochemical and morphological alterations of red blood cells. Int J Radiat Biol 2013; 89: 471-481.

52. Devipriya $N$, Sudheer AR, Srinivasan M, Menon VP. Quercetin ameliorates gamma radiation-induced DNA damage and biochemical changes in human peripheral blood lymphocytes. Mutat Res 2008; 645: 1-7.

53. Patil SL, Somashekarappa H, Rajashekhar $K$. Radiomodulatory role of rutin and quercetin in Swiss albino mice exposed to the whole body gamma radiation. Indian J Nucl Med 2012; 27: 237-242.

54. Patil SL, Mallaiah SH, Patil RK. Antioxidative and radioprotective potential of rutin and quercetin in Swiss albino mice exposed to gamma radiation. $J$ Med Phys 2013; 38: 87-92.
55. Sunada S, Fujisawa $H$, Cartwright IM, Maeda J, Brents $C A$, Mizuno $K$, Aizawa $Y$, Kato TA, Uesaka $M$. Monoglucosyl-rutin as a potential radioprotector in mammalian cells. Mol Med Rep 2014; 10: 10-14.

56. Qi L, Liu CY, Wu WQ, Yang JC, Sheng WH. Effects of flavonoids of Astragali Complanali against damage induced by 60 Co $y$-ray irradiation. Suzhou University Journal of Medical Science 2008; 28: 26-29.

57. Benković V, Orsolić $N$, Knezević AH, Ramić S, Dikić D, Basić I, Kopjar N. Evaluation of the radioprotective effects of propolis and flavonoids in gamma-irradiated mice: the alkaline comet assay study. Biol Pharm Bull 2008; 31: 167-172.

58. Benkovic V, Knezevic AH, Dikic D, Lisicic D, Orsolic N, Basic I, Kosalec I, Kopjar N. Radioprotective effects of propolis and quercetin in $\gamma$-irradiated mice evaluated by the alkaline comet assay. Phytomedicine 2008; 15: 851858.

59. Zhou Y, Mi MT. Genistein stimulates hematopoiesis and increases survival in irradiated mice. J Radiat Res 2005; 46: 425-433.

60. Xu Ping, Jia JQ, Jia JF, Jiang EJ. Radioprotective effects of troxerutin against gamma irradiation in mice liver. Int $J$ Radiat Biol 2012; 88: 607-612.

61. Guo XW, Hong CJ, Zhang BG. Quercetin on Hela and V79 cells radiation sensitivity. Chin J Radiol Med Prot 2010; 30: 572-573.

62. Hillman GG, Singh-Gupta V, Lonardo F, Hoogstra DJ, Abernathy LM, Yunker CK, Rothstein SE, Rakowski J, Sarkar FH and Gadgeel S. Radioprotection of lung tissue by soy isoflavones. J Thorac Oncol 2013; 11: 1356-1364.

63. Wang J, XU HW, Li BS, Zhang J, Cheng J. Preliminary study of protective effects of flavonoids against radiation-induced lung injury in mice. Asian Pacific $J$ Cancer Prev 2012; 13: 6441-6446.

64. Yuan H, Guo DH, Liu P, Cao JJ, Wang XP, Yin J, Zhu Y, Rahmanb $K$. Bioactive components from the tea polyphenols influence on endogenous antioxidant defense system and modulate inflammatory cytokines after total-body irradiation in mice. Phytomedicine 2011; 18: 970-975.

65. Lee EK, Kim JM, Choi J, Jung KJ, Kim DH, Chung SW, Ha YM, Yu BP, Chung HY. Modulation of NF-KB and FOXOs by baicalein attenuates the radiation induced inflammatory process in mouse kidney. Free Radical Res 2011; 45: 507-517.

66. Benković $V$, Knezević $A H$, Dikić $D$, Lisicić $D$, Orsolić $N$, Basić I, Kopjar N. Radioprotective effects of quercetin and ethanolic extract of propolis in gamma-irradiated mice. Arh Hig Rada Toksikol 2009; 60: 129-138.

67. Benković V, Kopjar N, Horvat Knezevic A, Dikić D, Basić I, Ramić S, Viculin T, Knezević F, Orolić N. Evaluation of radioprotective effects of propolis and quercetin on human white blood cells in vitro. Biol Pharm Bull 2008; 31: 1778-1785.

68. Orsolić N, Benković V, Horvat-Knezević A, Kopjar $N$, Kosalec I, Bakmaz M, Mihaljević Z, Bendelja K, Basić I. 
Assessment by survival analysis of the radioprotective properties of propolis and its polyphenolic compounds. Biol Pharm Bull 2007; 30: 946-951.

69. Yang LX, Yang GL, Du $H$, Bian F, Ning SP. Licorice flavonoids HaCaT cells express IL-10 after the UVB radiation. Chin J Lepr Skin Dis 2011; 27: 170-172.

70. Liu Y, Liu F, Yang Y, Li D, Lv J, Ou Y, Sun F, Chen J, Shi $Y$, Xia P. Astragalus polysaccharide ameliorates ionizing radiation-induced oxidative stress in mice. Int $J$ Macromol 2014; 68: 209-214.

71. Li YR, Cao W, Guo J, Miao S, Ding GR, Li KC, Wang J, Guo GZ. Comparative investigations on the protective effects of rhodioside, ciwujianoside- $B$ and astragaloside $I V$ on radiation injuries of the hematopoietic system in mice. Phytother Res 2011; 25: 644-653.

72. Khan R, Khan AQ, Qamar W, Lateef M, Tahir M, Rehman $M U$, Ali F, Sultana S. Chrysin protects against Cisplatininduced colon. Toxicity via amelioration of oxidative stress and apoptosis: probable role of p38MAPK and p53. Toxicol Appl Pharm 2012; 258: 315-329.
73. Tian $Y$, Sun $L M$, Liu XQ, Li B, Wang $Q$, Dong JX. Anti$H B V$ active flavone glucosides from euphorbia humifusa willd. Fitoterapia 2010; 81: 799-802.

74. Orhan DD, Ozçelik B, Ozgen S, Ergun F. Antibacterial, antifungal, and antiviral activities of some flavonoids. Microbiol Res 2010; 165: 496-504.

75. Liu W, LuX, He G, Gao X, Li M, Wu J, Wang J, Luo C. Cytosolic protection against ultraviolet induced DNA damage by blueberry anthocyanins and anthocyanidins in hepatocarcinoma HepG2 cells. Biotechnol Lett 2013; 35: 491-498.

76. Shin HA, Shin YS, Kang SU, Kim JH, Oh KH, Park KH, Lee $\mathrm{BH}$, Kim $\mathrm{CH}$. Radioprotective effect of epicatechin in cultured human fibroblasts and zebrafish. J Radiat Res 2014; 55: 32-40.

77. Singh VK, Grace MB, Parekh VI, Whitnall MH, Landauer MR. Effects of genistein administration on cytokine induction in whole-body gamma irradiated mice. Int Immunopharmacol 2009; 9: 1401-1410. 